\title{
The mind-body dilemma: a model for understanding women's mental health
}

\author{
Megan Jenkins \\ From 2013 ANZAED Conference: Inspiring Change: Person and Context \\ Melbourne, Australia. 23-24 August 2013
}

Body image dissatisfaction has been recognised as a key concern of Australian women, with longitudinal studies indicating that between $40 \%$ and $82 \%$ of women are unhappy with their body. Further, depression is the number one burden of disease among women and depressive symptoms and suicidal ideation represent a significant cost to both the individual and the community. Given the concurrently high rates of depression and body image disturbance in women, it is surprising that body image and disordered eating are not at the forefront of discussion regarding women's mental health.

The current paper will present a model of mental health for women that empirically tests and extends the Objectification Model (Frederickson \& Noll). The model of mental health offers important treatment implications for recovery and early intervention in women. Based on the proposed model, it is asserted that body image should be a key focus of research if we are to adequately understand women's mental health. Further, it is proposed that body image and disordered eating should be considered as playing a role in precipitating and maintaining psychological distress in women, even when no diagnosable eating disorder is present.

This abstract was presented in the Disordered Eating Characteristics \& Treatment stream of the 2013 ANZAED Conference.

Submit your next manuscript to BioMed Central and take full advantage of:

- Convenient online submission

- Thorough peer review

- No space constraints or color figure charges

- Immediate publication on acceptance

- Inclusion in PubMed, CAS, Scopus and Google Scholar

- Research which is freely available for redistribution
() Biomed Central 